The University of Maine

DigitalCommons@UMaine

Earth Science Faculty Scholarship

Earth Sciences

$12-27-1997$

\title{
Assessment of the Record of the 1982 El Chichón Eruption as Preserved in Greenland Snow
}

Gregory A. Zielinski

Jack E. Dibb

Qinzhao Yang

Paul Andrew Mayewski

University of Maine, paul.mayewski@maine.edu

Sallie Whitlow

See next page for additional authors

Follow this and additional works at: https://digitalcommons.library.umaine.edu/ers_facpub

Part of the Atmospheric Sciences Commons, Geochemistry Commons, Glaciology Commons, and the Hydrology Commons

\section{Repository Citation}

Zielinski, Gregory A.; Dibb, Jack E.; Yang, Qinzhao; Mayewski, Paul Andrew; Whitlow, Sallie; Twickler, Mark S.; and Germani, Mark S., "Assessment of the Record of the 1982 El Chichón Eruption as Preserved in Greenland Snow" (1997). Earth Science Faculty Scholarship. 244.

https://digitalcommons.library.umaine.edu/ers_facpub/244

This Article is brought to you for free and open access by DigitalCommons@UMaine. It has been accepted for inclusion in Earth Science Faculty Scholarship by an authorized administrator of DigitalCommons@UMaine. For more information, please contact

um.library.technical.services@maine.edu. 
Authors

Gregory A. Zielinski, Jack E. Dibb, Qinzhao Yang, Paul Andrew Mayewski, Sallie Whitlow, Mark S. Twickler, and Mark S. Germani 


\title{
Assessment of the record of the 1982 El Chichón eruption as preserved in Greenland snow
}

\author{
Gregory A. Zielinski, Jack E. Dibb, Qinzhao Yang, Paul A. Mayewski, Sallie \\ Whitlow, and Mark S. Twickler \\ Climate Change Research Center, University of New Hampshire, Durham
}

Mark S. Germani

MVA, Inc., Burr Ridge, Illinois

\begin{abstract}
Variability in the $\mathrm{SO}_{4}^{2-}$ and $\mathrm{Cl}^{-}$time series for the 1980 s from 12 shallow snow pits across the Greenland ice sheet is used to evaluate the record of the 1982 El Chichón eruption and the potential for recording a moderate northern equatorial eruption in a single Greenland ice core. Composition of volcanic glass found in spring 1983 snow in one of the pits in the Summit region matches that from $\mathrm{El}$ Chichón glass, thereby verifying the deposition of material from the eruption. High $\mathrm{Na}^{+}$and $\mathrm{Cl}^{-}$concentrations in this same layer probably represent deposition of the reaction products of halite and $\mathrm{H}_{2} \mathrm{SO}_{4}$ as observed in the stratosphere following the eruption. These findings and the presence of a $\mathrm{Cl}^{-}$signal in five of the other pits indicate that the $\mathrm{Cl}^{-}$aerosol component of some eruptions has the potential to remain aloft for at least 1 year after the eruption. Some of these aerosols may be adsorbed onto tephra particles. Distinct $\mathrm{SO}_{4}^{2-}$ peaks that can be confidently linked to El Chichón were found in only $50 \%$ of the records developed through subseasonal sampling. However, in several other pits an elevated baseline, thought to represent more lengthy periods of El Chichón aerosol deposition as opposed to deposition from a single snowfall event, were observed. Smoothing of the original data by the calculation of annual $\mathrm{SO}_{4}^{2-}$ flux resulted in the presence of high flux values between 1982 and 1984 (years thought to be affected by El Chichón aerosol deposition) in 9 of the 12 pits. These results suggest that a single ice core from anywhere in Greenland may record a signal from a northern equatorial eruption of magnitude similar to that of El Chichón about $75 \%$ of the time; this is despite the overall high levels of $\mathrm{SO}_{4}^{2-}$ deposition from anthropogenic sources that now make identification and quantification of the volcanic $\mathrm{SO}_{4}^{2-}$ portion of the record more difficult than obtaining the same data for preindustrial volcanism. Nevertheless, composite records from all the pits sampled yielded stratospheric loading ( 20 Mt) and optical depth $(\tau=0.13)$ estimates similar to stratospheric and satellite-based measurements following the eruption. Equally high $\mathrm{SO}_{4}^{2-}$ concentration and flux values in snow from 1980 to 1982 reflect deposition from the series of middle to high northern latitude volcanic eruptions 1979-1981.
\end{abstract}

\section{Introduction}

Between March 28 and April 4, 1982, the plinian eruptions of El Chichón, Mexico $\left(17^{\circ} \mathrm{N}, 121^{\circ} \mathrm{W}\right)$, injected large quantities of debris into the northern equatorial stratosphere with the eventual dispersion over the entire globe. Estimates of the amount of $\mathrm{SO}_{2}$ released vary from 8 [Bluth et al., 1993] to $13 \mathrm{Mt}$ (i.e., $10^{12} \mathrm{~g}$ or

Copyright 1997 by the American Geophysical Union.

Paper number 97JD01574.

0148-0227/97/97JD-01574\$09.00
$\mathrm{Tg}$ ) [Evans and Kerr, 1983], leading to the initial production of about 12 [McCormick et al., 1995] to $20 \mathrm{Mt}$ of $\mathrm{H}_{2} \mathrm{SO}_{4}$ [Evans and Kerr, 1983; Hofmann and Rosen, 1983; Rampino and Self, 1984]. Thus El Chichón may have injected more sulfur-rich aerosols into middle levels of the atmosphere than any eruption in this century except for the 1991 eruption of Mt. Pinatubo. Subsequently, it was expected that evidence of the atmospheric loading of the El Chichón aerosols would be preserved in polar snow through the presence of high peaks in $\mathrm{SO}_{4}^{2-}$ [e.g., Legrand and Delmas, 1987; Mayewski et al., 1993; Zielinski et al., 1994], and particularly in Arctic snow, given the $17^{\circ} \mathrm{N}$ location of the volcano. Sur- 


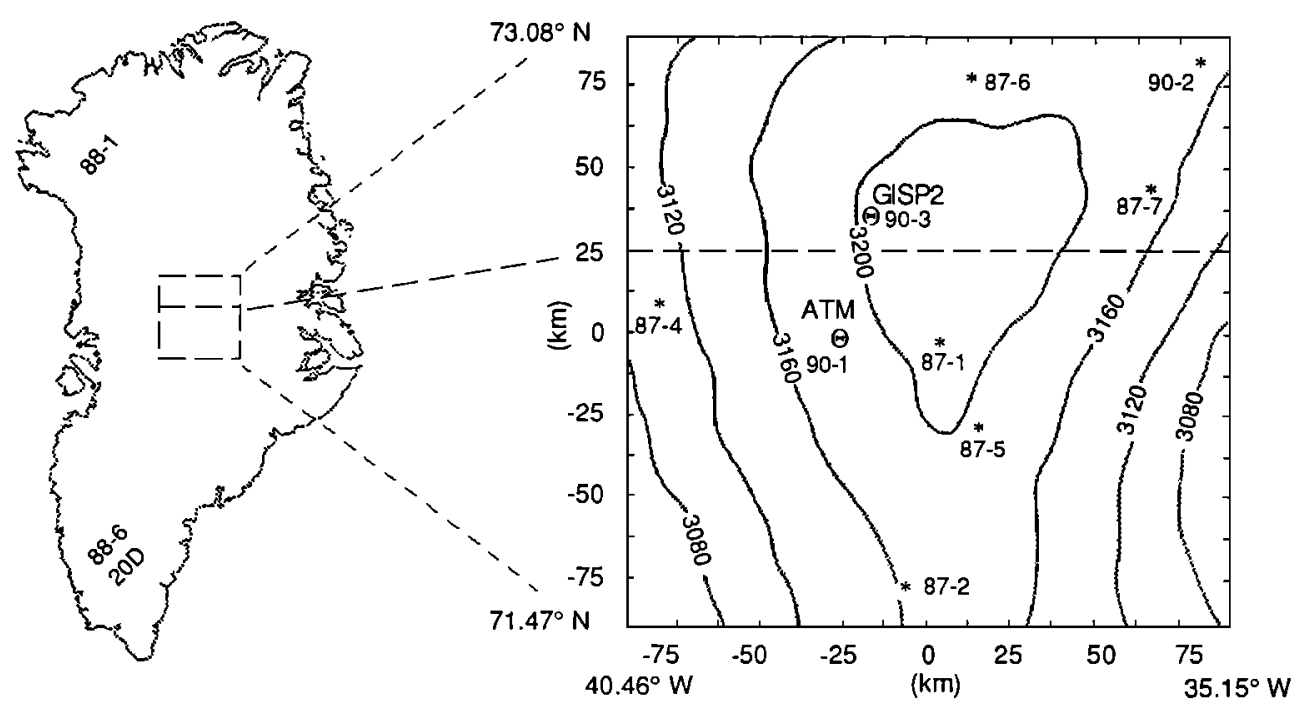

Figure 1. Location of Greenland snow pits used in this study together with location of the GISP2 ice coring site and the Atmospheric Sampling Camp (ATM). Modified from Yang et al. [1996].

prisingly, there is no discernible signal in the biyearly $\mathrm{SO}_{4}^{2-}$ record from the Greenland Ice Sheet Project 2 (GISP2) ice core that can be confidently linked to the El Chichón eruption [Zielinski et al., 1994; Zielinski, 1995].

To determine whether or not there is evidence of the El Chichón eruption in Greenland snow and ultimately to assess the consistency (both temporally and spatially) and magnitude of the signal, we evaluated the variability in snow chemistry at a subseasonal resolution in a series of shallow snow pits across Greenland. The majority of the pits are located in the Summit region (i.e., within $75 \mathrm{~km}$ of the GISP2 drilling site), although we include the evaluation of several pits in northern and southern Greenland (Figure 1). The results of this study are used to answer three interrelated questions in the use of polar snow and ice cores to evaluate past volcanism.

The first critical question we address is how likely it is for the chemical signal of a moderate-sized equatorial eruption to be present in a single ice core collected from Greenland, assuming that the chemical record we see in the snow pits would be identical to that found in an ice core collected at the same site. In order for a volcanic signal to exist in an ice core, several criteria must be met. Circulation patterns must bring the volcanic cloud over the coring site followed by deposition of the aerosols via a snow event(s). Finally, there must be minimal postdepositional modification of the volcanic acids that would result in a missing signal for a particular eruption (e.g., wind scouring without redeposition at the site in question). Clausen and Hammer [1988] used multiple Greenland ice cores to evaluate the variability in the Icelandic Laki (A.D. 1783; $\sim 200 \mathrm{Mt} \mathrm{H}_{2} \mathrm{SO}_{4}$ ) and Indonesian Tambora (A.D. 1815; $\sim 200 \mathrm{Mt} \mathrm{H}_{2} \mathrm{SO}_{4}$; see also Rampino et al. [1988]) erup- tions, but these are the largest sulfur-producing eruptions during historical time (i.e., an order of magnitude greater than El Chichón). As a result, signals for these two eruptions have been observed in all northern hemisphere ice cores that we are aware of. Robock and Free [1995] essentially stacked volcanic records from eight northern hemisphere ice cores that span the last 150 years and found that only the Alaskan Katmai eruption (A.D. 1912; 30-40 Mt $\mathrm{H}_{2} \mathrm{SO}_{4}$ [e.g., McCormick et al., 1995]) is consistently preserved in these records. Katmai is directly upwind from Greenland and other ice caps in the Arctic, and this situation would enable aerosols to be readily transported to those deposition sites, with the probability of some tropospheric transport. Although the El Chichón eruption is moderate in the overall scheme of climate-forcing volcanism, it still may have cooled global climate by $0.35^{\circ} \mathrm{C}$ once the warming effects of the coincident El Niño were accounted for [Angell, 1988]. Identifying the likelihood of missing similar magnitude, equatorial eruptions in ice cores is important in the evaluation of the interannual to decadal variability of past climate. Our results can best be applied to evaluating the climatic impact of past volcanism from the Central America/Caribbean region, areas whose volcanoes are known to have been much more active and explosive in prehistoric time in comparison with the present [e.g., Siebe et al., 1996].

The second question of importance is how much the signal:noise ratio of a volcanic $\mathrm{SO}_{4}^{2-}$ peak decreases with detailed, subseasonal sampling. To address this question, we will compare the annual signals from these same pits to test whether the years following the El Chichón eruption are characterized by higher overall $\mathrm{SO}_{4}^{2-}$ deposition in comparison with the years before the eruption or beyond the suspected residence time of the aerosols in the atmosphere. In essence, the com- 
parison of annual signals versus subseasonal signals is a form of smoothing of the original data set, which should increase the signal:noise ratio. We will be able to determine whether such a smoothing results in a more consistent signal across the Greenland ice sheet from the El Chichón eruption, even though there was not a distinct El Chichón signal in the highly smoothed, biannual sampling of the GISP2 core.

The third question we are able to provide insight into is how well we can use recent eruptions to calibrate the volcanic record in ice cores. For instance, using the snow and ice records of the El Chichón and Pinatubo eruptions to quantify the stratospheric loading of each eruption [e.g., Hammer et al., 1980; Zielin$s k i, 1995]$ would enable direct comparisons to be made with the atmospheric loading estimates derived from direct stratospheric [e.g., Hofmann and Rosen, 1983] and satellite-based measurements [e.g., Bluth et al., 1993]. The potential problem with this scenario is that for recent eruptions, anthropogenic sulfur emissions may be of such a magnitude that the $\mathrm{SO}_{4}^{2-}$ signal in recent snow from moderate eruptions like El Chichón may not be sufficient to yield a distinct spike in the record. By evaluating the series of snow pits across Greenland and developing composite concentration and flux records we will be better able to identify the range in values of volcanic deposition on the Greenland ice sheet for comparison with the values obtained for eruptions prior to the increase in $\mathrm{SO}_{4}^{2-}$ deposition from anthropogenic sources [Zielinski, 1995]. Adding support to the idea that high levels of anthropogenic $\mathrm{SO}_{4}^{2-}$ deposition on the ice sheet [e.g., Mayewski et al., 1986, 1990] may inhibit the detection of a volcanic signal is the absence of a clear signal from the deposition of Pinatubo aerosols ( $\sim 2-3$ times greater mass than El Chichón [McCormick et al., 1995]) in snow deposited on Greenland and on other Arctic ice caps during the years after the eruption. However, there is a Pinatubo signal in snow at the south pole [Dibb and Whitlow, 1996], snow that is not as affected by anthropogenic sources as is Greenland [Whitlow et al., 1992]. Should we be able to extract a composite volcanic signal for El Chichón, we will estimate the stratospheric loading of $\mathrm{H}_{2} \mathrm{SO}_{4}$ aerosols and the resulting optical depth [e.g., Zielinski, 1995] for comparison with previously published estimates, including satellitederived estimates.

\section{Aerosol Distribution and Other Products of the El Chichón Eruption}

The expected timing of the deposition of any chemical signal in Greenland snow from El Chichón may be inferred by the global distribution of the aerosol cloud. (Note that a special issue of Geophysical Research Letters, volume 10, 1983, presented many of the initial results of the atmospheric impact of the eruption.) The main aerosol cloud circumnavigated the globe around the latitude of the eruption within about 3 weeks [Robock and Matson, 1983], eventually extending throughout the northern tropics by the end of May 1982. At that time the cloud consisted of two separate layers: one from the tropopause $(12-16 \mathrm{~km})$ to about a height of $20 \mathrm{~km}$ and the other centered around $25 \mathrm{~km}$ [Hofmann and Rosen, 1983]. Most of the cloud above $20 \mathrm{~km}$ remained in the tropics until late August and September 1982, when some intermittent northward transport occurred [Hofmann and Rosen, 1983]. Eventually, atmospheric transport mechanisms dispersed the cloud to the point where it covered the entire northern hemisphere by early 1983 [Hofmann, 1987]. Consequently, we did not expect to see aerosol deposition in Greenland until possibly fall 1982 . However, the lower aerosol layer reached the midlatitudes $\left(41^{\circ} \mathrm{N}\right)$ by June 1982 [Hofmann and Rosen, 1983]; thus some aerosols could have reached Greenland during summer/fall 1982, given ideal circulation patterns.

In addition to the sulfur component, several other products of importance to our study were released during the El Chichón eruption. Mankin and Coffey [1984] reported increased $\mathrm{HCl}$ levels in the stratosphere over northern midlatitudes for several months following the eruption. Using this information, they suggested a total stratospheric loading of $0.04 \times 10^{6} \mathrm{Mt} \mathrm{HCl}$ from the eruption itself, a $40 \%$ increase over preeruption levels. Woods et al. [1985] used scanning electron microscopy (SEM) and X ray energy spectroscopy on particles collected in the lower stratosphere $(18-21 \mathrm{~km})$ over the western United States during April and May 1982 to identify the presence of halite in the eruption cloud. Halite was no longer observed after July 1982, as most of the halite particles probably converted to $\mathrm{Na}_{2} \mathrm{SO}_{4}$ and $\mathrm{HCl}$ through reactions with $\mathrm{H}_{2} \mathrm{SO}_{4}$ within the first month following the eruption [Woods et al., 1985]. Complete conversion probably occurred within 8 months after the eruption. As a result, evidence of aerosol deposition on the Greenland ice sheet from El Chichón may be through peaks in both $\mathrm{SO}_{4}^{2-}$ and $\mathrm{Cl}^{-}$.

The mineralogical component of the eruption (i.e., tephra) remained a significant part of the stratospheric aerosol cloud over the Americas until October 1982 [Gooding et al., 1983]. The northward spread of tephra over almost all of the northern hemisphere may have occurred within 6 months following the eruption. Tephra was observed consistently at middle to high latitudes $\left(45-75^{\circ} \mathrm{N}\right)$ into late October, although parts of the ash component spread to $60^{\circ} \mathrm{N}$ by July 1982 . About $85 \%$ of the ash sampled at latitudes of $>45^{\circ} \mathrm{N}$ in October of 1982 was in the $2-5 \mu \mathrm{m}$ (intermediate diameter) size range, with another $11 \%$ in the $5-10 \mu \mathrm{m}$ size range [Gooding, 1983]. The timing of the presence of tephra in the Arctic atmosphere and deposition on the Greenland ice sheet was documented in two separate studies. De Angelis et al. [1985] identified the presence of volcanic glass from El Chichón in snow collected in June 1983 from the Dye 3 site in southern Greenland. How- 


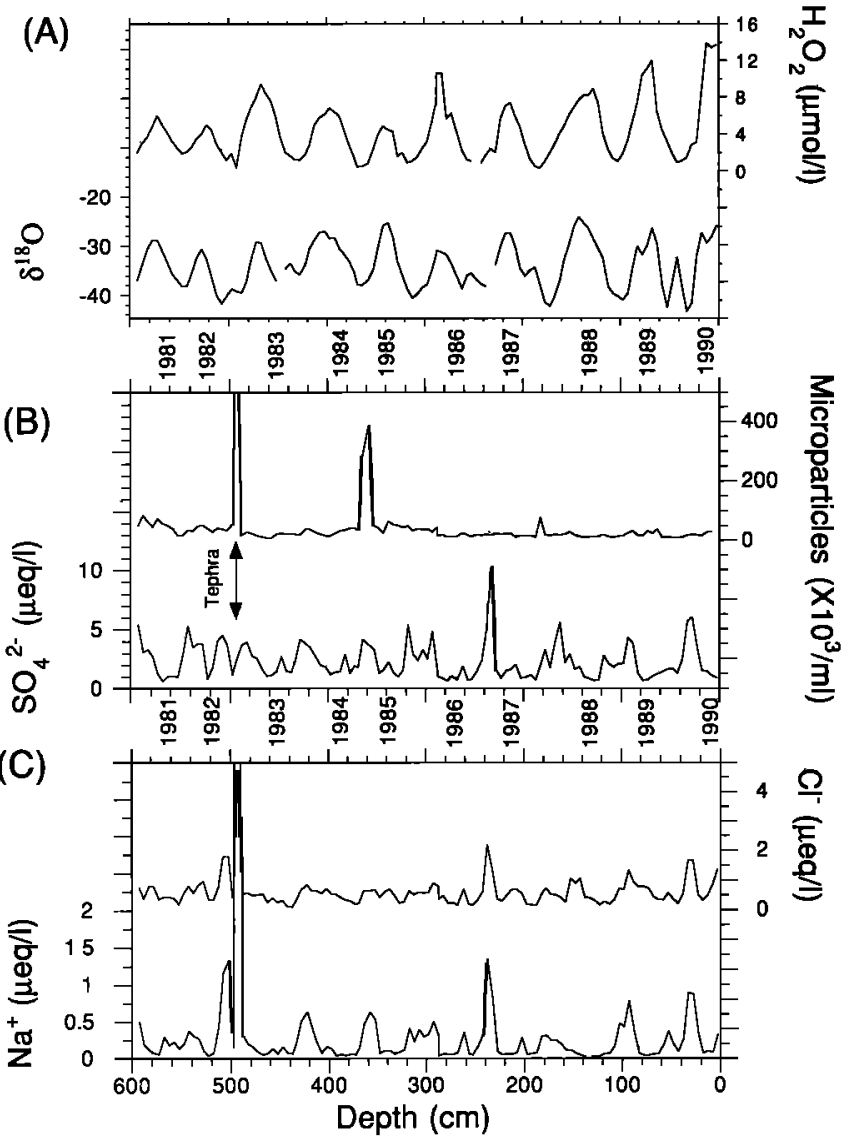

Figure 2. Time series of (a) $\delta^{18} \mathrm{O}$ and $\mathrm{H}_{2} \mathrm{O}_{2}$, (b) $\mathrm{SO}_{4}^{2-}$ and insoluble microparticles, and $\mathrm{Na}^{+}$and $\mathrm{Cl}^{-}$for pit 90-1. Location of the sample that contained volcanic glass (tephra) is shown in Figure 2b. Year designation indicates depth of midsummer snow for that particular year.

ever, they suggest that there may have been deposition as early as June 1982. Shapiro et al. [1984] collected mineral matter believed to be from El Chichón during a tropopause fold event over west central Greenland on March 23, 1983. Small droplets (diameter of $<0.5 \mu \mathrm{m}$ ) thought to be $\mathrm{H}_{2} \mathrm{SO}_{4}$ from El Chichón were found on the same filter. On the basis of these data it is possible that volcanic glass traveling in the stratosphere may have been deposited on the Greenland Ice Sheet anytime between midsummer 1982 and the spring to summer 1983. Any tephra transported tropospherically could possibly have reached Greenland within several weeks of the eruption, given ideal synoptic conditions. Identifying tephra from El Chichón in the same layer as a $\mathrm{SO}_{4}^{2-}$ or $\mathrm{Cl}^{-}$peak verifies the presence of aerosols from the eruption in Greenland snow.

\section{Methods of Analysis}

All snow pit samples were collected with personnel in clean suits to prevent possible contamination following the procedures outlined by Mayewski et al. [1987]. Samples remained frozen until the time of analysis. An- ions and cations were analyzed using a Dionex model 2010 ion chromatograph. Duplicate samples and blanks were frequently analyzed to detect any possible contamination, as described by Buck et al. [1992]. $\mathrm{All} \mathrm{SO}_{4}^{2-}$ values in this study have been corrected for the sea-salt component, which is usually $<5 \%$ of total $\mathrm{SO}_{4}^{2-}$. Insoluble microparticle concentrations and size distributions between 0.65 and $12.88 \mu \mathrm{m}$ were obtained with an Elzone $280 \mathrm{PC}$ particle counter in a class 100 clean room. Meltwater samples were filtered through a Nucleopore polycarbonate membrane filter $(0.4 \mu \mathrm{m}$ pore size) in an attempt to locate volcanic glass. Individual particle analyses were undertaken with an automated Jeol JXA-8600 electron microprobe. The chronology developed for all pits in this study was based on the seasonal variability (i.e., summer peaks and winter troughs) of specific parameters such as $\delta^{18} \mathrm{O}$ and $\mathrm{H}_{2} \mathrm{O}_{2}$. A total of nine pits were analyzed in the Summit region, one pit was analyzed from northwestern Greenland, and two pits were analyzed from southern Greenland (Figure 1). Snow density measurements were taken on the same layer as chemistry and microparticle samples in pit 90-1 to determine the annual flux of specific species. Density gradually increased from mean values of $315 \mathrm{~kg} / \mathrm{m}^{3}$ in the upper $250 \mathrm{~cm}$ to $385 \mathrm{~kg} / \mathrm{m}^{3}$ between 250 and 500 $\mathrm{cm}$ to $450 \mathrm{~kg} / \mathrm{m}^{3}$ between 500 and $600 \mathrm{~cm}$. This general trend is similar to density trends observed in surface snow throughout Greenland (R. Alley, personal communication, 1993]; thus these mean values were used to determine flux values in all other pits analyzed. Resulting errors for flux values are thought to be between $5 \%$ and $10 \%$.

\section{Glaciochemical Time Series}

\subsection{Pit 90-1, Summit Region}

One of the most detailed analyses in this study was on the $6 \mathrm{~m}$ pit, 90-1, located at the Atmospheric Sampling Camp (ATM), southern Summit region (Figure 1). Sampling interval in this pit was $5 \mathrm{~cm}$, yielding about 15 samples/yr for chemistry and insoluble microparticle analysis. The record extends from summer 1990 to spring/early summer 1981 based on counting of peaks in $\delta^{18} \mathrm{O}$ and $\mathrm{H}_{2} \mathrm{O}_{2}$ (Figure 2). Spring 1982, the time of the El Chichón eruption, is represented by snow at about the $550 \mathrm{~cm}$ depth.

Several interesting signals are prevalent in the time series of the various ions and insoluble microparticles (Figures $2 \mathrm{~b}$ and 2c). Initially, our interest was drawn to the very high microparticle peak around $500 \mathrm{~cm}$ (corresponding to deposition late in 1982 or early 1983, Figure $2 \mathrm{~b}$ ) because the high microparticle loading could be indicative of a large amount of volcanic glass deposition [e.g., Fiacco et al., 1993]. Although the SEM/microprobe analysis of meltwater from this section of the pit indicated that some of these particles were contamination from the stainless steel sampling tool, two populations of glass shards were found (Figure 3 and Table 1). 

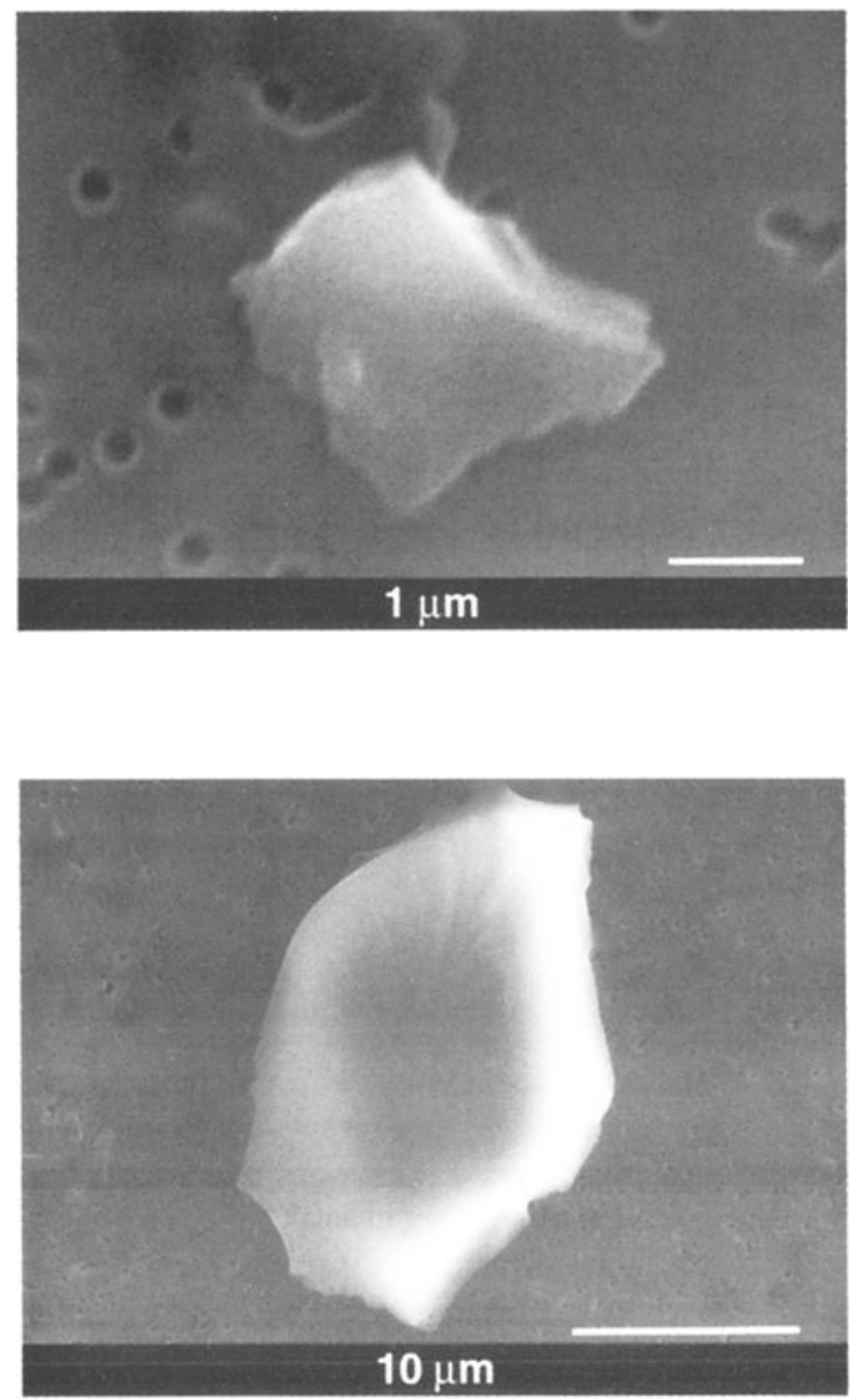

Figure 3. Photomicrographs of typical volcanic glass shards representative of (top) glass $A$ and (bottom) glass B from the $495-500 \mathrm{~cm}$ depth (winter 1982/spring 1983 ) in pit $90-1$ (Figure 2).
Glass A has a rhyolitic to trachydacitic composition with a high alkalic component $\left(\mathrm{Na}_{2} \mathrm{O}\right.$ and $\mathrm{K}_{2} \mathrm{O}$; Table 1) characteristic of the El Chichón eruption. Glass $B$ is much different, having a highly rhyolitic composition (Table 1). Glass A shards were much smaller on average, with long axes often in the $2-4 \mu \mathrm{m}$ size range, whereas glass B shards had long axes that were often 10-20 $\mu \mathrm{m}$ (Figure 3).

Verification of the source of glass A comes from direct comparison with the composition of El Chichón glass that we analyzed, as well as previous analyses of El Chichón glass (Figure 4 and Table 1). The composition of individual glass grains in pit 90-1 consistently overlaps that of El Chichón glass, and the mean values are almost identical (Figure 4). Further, the mean composition of the glass we analyzed closely matches the mean value of glass analyzed from El Chichón pumice [Luhr et al., 1984], thus verifying El Chichón as the source. A late fall 1982 to early spring 1983 time of glass deposition also fits well with the timing of the northward distribution of tephra [Gooding et al., 1983] and the possible presence of El Chichón mineral matter in a tropopause fold event over Greenland in spring 1983 [Shapiro et al., 1984]. The presence of El Chichón glass in the same layer as large spikes in $\mathrm{Na}^{+}$and $\mathrm{Cl}^{-}$ (Figure 2c) has some interesting ramifications that we elaborate on below.

Identification of the source of glass B in this same layer is problematic. Many of the other large eruptions in 1981 (e.g., Alaid, Pagan, and Nyamuragira; see Table 2) are characterized by a basaltic composition [i.e., McClelland et al., 1989], thereby eliminating them as a possible source. The 1982 eruption of Galunggung is another possible source, but this volcanic system also is generally less silicic than our glass B [i.e., McClelland et al., 1989]. Consequently, we feel that the most plausible source of glass $b$ is the rapid tropospheric transport of

Table 1. Average Major Elemental Composition of Volcanic Glass Found at the 495-500 cm Depth of the 90-1 Snow Pit Compared With Glass From El Chichón

\begin{tabular}{lccrrrr}
\hline & $\begin{array}{c}\text { Pit 90-1 } \\
\text { Glass A } \\
(\mathrm{n}=8)\end{array}$ & $\begin{array}{c}\text { Pumice } \\
\text { Glass } \\
(\mathrm{n}=9)\end{array}$ & $\begin{array}{c}\text { Pumice } \\
\text { Glass }^{\mathrm{a}} \\
(\mathrm{n}=16)\end{array}$ & $\begin{array}{c}\text { Stratosphere }^{\mathrm{b}} \\
(\mathrm{n}=15)\end{array}$ & $\begin{array}{c}\text { Snow } \\
\text { Dye 3 } \\
(\mathrm{n}=6)\end{array}$ & $\begin{array}{c}\text { Pit 90-1 } \\
\text { Glass B } \\
(\mathrm{n}=5)\end{array}$ \\
\hline $\mathrm{SiO}_{2}$ & $71.2(1.0)^{\mathrm{c}}$ & $71.1(1.0)$ & $68.0(1.7)$ & $69.4(1.3)$ & $69.2(0.5)$ & $78.1(1.2)$ \\
$\mathrm{TiO}_{2}$ & $0.3(0.3)$ & $0.4(0.1)$ & $0.3(0.1)$ & $0.3(0.1)$ & $0.4(0.2)$ & $0.2(0.2)$ \\
$\mathrm{Al}_{2} \mathrm{O}$ & $14.8(0.3)$ & $15.5(0.6)$ & $15.9(0.4)$ & $17.9(0.6)$ & $17.1(0.2)$ & $11.9(0.4)$ \\
$\mathrm{Fe}_{2} \mathrm{O}_{3}$ & $1.7(0.6)$ & $1.8(0.2)$ & $1.6(0.2)$ & $1.4(0.4)$ & $1.9(0.5)$ & $1.9(0.4)$ \\
$\mathrm{MgO}$ & $0.4(0.3)$ & $0.3(0.2)$ & $0.3(0.1)$ & $0.4(0.1)$ & $0.4(0.1)$ & $0.1(0.2)$ \\
$\mathrm{CaO}$ & $1.8(0.5)$ & $2.0(0.2)$ & $2.1(0.2)$ & $1.9(0.3)$ & $1.8(0.2)$ & $1.5(0.3)$ \\
$\mathrm{Na}_{2} \mathrm{O}$ & $4.4(0.6)$ & $2.9(0.9)$ & $4.6(0.5)$ & $3.9(0.8)$ & $4.5(0.7)$ & $3.4(1.4)$ \\
$\mathrm{K}_{2} \mathrm{O}$ & $5.2(0.7)$ & $6.0(0.4)$ & $5.1(0.2)$ & $4.7(0.4)$ & $4.8(0.3)$ & $3.0(1.0)$ \\
\hline
\end{tabular}

a Reprinted from Journal of Volcanology and Geothermal Research, 23, Luhr et al., The 1982 eruptions of El Chichón volcano, Chiapas, Mexico: Mineralogy and petrology of the anhydrite-bearing pumices, Copyright 1984 with kind permission from Elsevier ScienceNL, Sara Burgerhartstraat 25, $1055 \mathrm{KV}$ Amsterdam, The Netherlands. Total Fe reported as $\mathrm{FeO}$.

'Reprinted with permission from Nature (De Angelis et al., 317, 52-54), Copyright 1985, Macmillan Magazines Limited and from M. De Angelis. Total Fe reported as FeO.

cValue in parentheses is $1 \sigma$. 


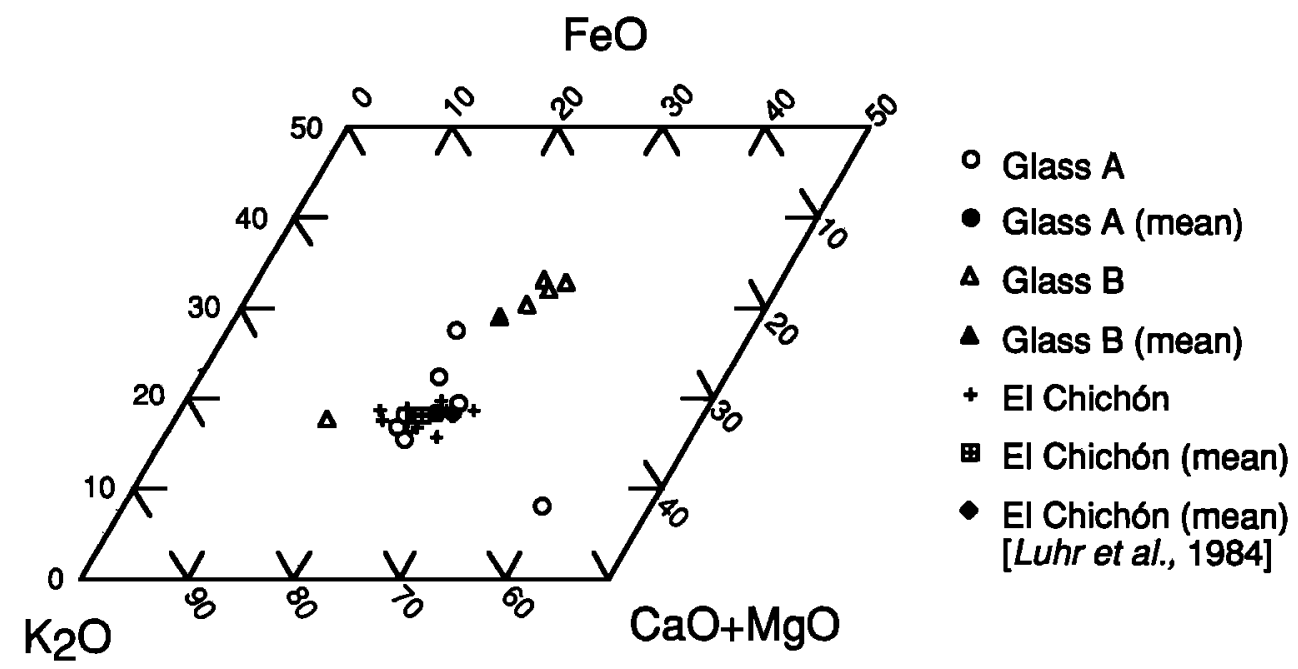

Figure 4. Ternary diagram comparing the composition of the volcanic glass found in pit 90-1 with that from the El Chichón eruption.

tephra to Greenland from the small May 22, 1983, eruption of Bezymianny, Kamchatka. Eruptions of Bezymianny over the last few decades appear to be becoming more silicic than prior eruptions, and in fact, the 1956 event appears to have tapped a rhyolitic magma source [Palais and Sigurdsson, 1989]. Furthermore, the overall larger size of glass B shards compared with those of glass A supports a more proximal or directly upwind source, like Bezymianny, for glass B. Because evaluation of the products of the 1956 Bezymianny eruption indicate that this volcanic system contains a source of $\mathrm{Cl}^{-}$ [Palais and Sigurdsson, 1989], we cannot rule out completely the possibility that some of the chemical signal found in this section of pit 90-1 is a result of the 1983 Bezymianny eruption. However, the small size of that eruption $\left(10^{7} \mathrm{~m}^{3}\right.$ ash erupted to only 5-6 $\mathrm{km}$ altitude) and the probable ESE transport of material $[\mathrm{McClel}-$ land et al., 1989] lead us to believe that most of the chemical signal in 1982/1983 snow in pit 90-1 is related to El Chichón aerosol deposition.

Identifying the presence of El Chichón debris in the Summit region of Greenland through the existence of volcanic glass enables us to more readily characterize the $\mathrm{SO}_{4}^{2-}$ and $\mathrm{Cl}^{-}$signals from the eruption. In the case of the $\mathrm{SO}_{4}^{2-}$ signal the first impression is that there is no anomalous spike in pit 90-1 (Figure 2b). It is only the large spike around spring 1987 that is very prominent. That enhancement could be related to aerosols from the 1986 eruptions of St. Augustine and Chikurachki in the northern Pacific (Table 1). However, it should be noted that there is a broad, but subdued, peak in $\mathrm{SO}_{4}^{2-}$ that corresponds to fall/winter 1982 and possibly very early spring 1983 (i.e., just prior to the time when El Chichón tephra was deposited). This peak is not larger

Table 2. Explosive Eruptions That May be Responsible for Peaks in $\mathrm{SO}_{4}^{2-}$ and $\mathrm{Cl}^{-}$Recorded in Greenland Snow Pits During the 1980s

\begin{tabular}{lllrrl}
\hline Year & Date & \multicolumn{1}{c}{ Volcano } & Latitude & Longitude & VEI \\
\hline 1979 & Feb. 8 & Westdahl, Alaska & $54.5^{\circ} \mathrm{N}$ & $164.6^{\circ} \mathrm{W}$ & $3 ?$ \\
1979 & Nov. 13 & Sierra Negra, Galapagos & $0.8^{\circ} \mathrm{S}$ & $91.2^{\circ} \mathrm{W}$ & 3 \\
1980 & May 18 & St. Helens, Washington & $46.2^{\circ} \mathrm{N}$ & $122.2^{\circ} \mathrm{W}$ & 5 \\
1980 & Aug. 7 & Gareloi, Alaska & $51.8^{\circ} \mathrm{N}$ & $178.8^{\circ} \mathrm{W}$ & $3 ?$ \\
1981 & March 24 & Okmok, Alaska & $53.4^{\circ} \mathrm{N}$ & $168.1^{\circ} \mathrm{W}$ & $3 ?$ \\
1981 & April 30 & Alaid, Kuril Islands & $50.9^{\circ} \mathrm{N}$ & $155.6^{\circ} \mathrm{E}$ & 4 \\
1981 & May 15 & Pagan, Mariana Islands & $18.1^{\circ} \mathrm{N}$ & $145.8^{\circ} \mathrm{E}$ & 4 \\
1981 & Dec. 25 & Nyamuragira, Zaire & $1.4^{\circ} \mathrm{S}$ & $29.2^{\circ} \mathrm{E}$ & 3 \\
1982 & March 28 & El Chichón, Mexico & $17.4^{\circ} \mathrm{N}$ & $93.2^{\circ} \mathrm{W}$ & $4+$ \\
1982 & April 3 & El Chichón, Mexico & $17.4^{\circ} \mathrm{N}$ & $93.2^{\circ} \mathrm{W}$ & 5 \\
1982 & May 17 & Galunggung, Java & $7.3^{\circ} \mathrm{S}$ & $108.1^{\circ} \mathrm{E}$ & 4 \\
1983 & July 23 & Colo (Una Una), Indonesia & $0.2^{\circ} \mathrm{S}$ & $121.6^{\circ} \mathrm{E}$ & 4 \\
1985 & Nov. 13 & Ruiz, Columbia & $4.9^{\circ} \mathrm{N}$ & $75.3^{\circ} \mathrm{W}$ & 3 \\
1986 & March 27 & St. Augustine, Alaska & $59.4^{\circ} \mathrm{N}$ & $153.4^{\circ} \mathrm{W}$ & $4 ?$ \\
1986 & Nov. 20 & Chikurachki, Kuril Islands & $50.3^{\circ} \mathrm{N}$ & $155.4^{\circ} \mathrm{E}$ & $4 ?$ \\
& & & & & \\
\hline
\end{tabular}

From Simkin and Siebert [1994]. VEI, volcanic explosivity index. 
than the annual spring peaks in $\mathrm{SO}_{4}^{2-}$ [Whitlow et al., 1992] that are clearly observed along the entire record in this pit. In fact, this bump has the appearance of an additional spring peak, but it is clear from the $\delta^{18} \mathrm{O}$ and $\mathrm{H}_{2} \mathrm{O}_{2}$ records (Figure 2a) that it is not such a peak. We suggest that much of the $\mathrm{SO}_{4}^{2-}$ in this broad peak is associated with deposition of the earliest El Chichón aerosols that reached the polar regions. This suggestion is supported in our later discussion on the annual flux of $\mathrm{SO}_{4}^{2-}$.

Perhaps the most distinct glaciochemical signals in this pit are the coincident peaks in both $\mathrm{Na}^{+}$and $\mathrm{Cl}^{-}$ in the same sample that contained the volcanic glass (Figures $2 \mathrm{~b}$ and $2 \mathrm{c}$ ). Interestingly, the $\mathrm{Na}: \mathrm{Cl} \mu$ eq ratio for this sample is $1: 1$, not $\mathbf{0 . 8 5}$, as would be the case if the $\mathrm{Na}^{+}$and $\mathrm{Cl}^{-}$were solely from sea-salt aerosols. The most likely cause for these high $\mathrm{Na}$ and $\mathrm{Cl}$ concentrations is the deposition of halite or, more likely, deposition of the by-products of halite dissolution following reactions with $\mathrm{H}_{2} \mathrm{SO}_{4}$ in the stratosphere (i.e., $\mathrm{Na}_{2} \mathrm{SO}_{4}$ and $\mathrm{HCl}$ [Woods et al., 1985]). The presence of stratospheric halite following the eruption could be the source of the halite products, and once these products were able to reach the northern polar regions, the very low relative humidity may have allowed the $\mathrm{HCl}$ component to stay gaseous for longer periods of time (R. Chuan, personal communication, 1992). Such a scenario would have prevented complete removal before deposition on the ice sheet. Alternatively, Varekamp et al. [1984] indicated that there was abundant $\mathrm{Na}$ (mean of $335 \mathrm{ppm}$ ) and $\mathrm{SO}_{4}$ (mean $780 \mathrm{ppm}$ ) within materials adsorbed onto tephra grains from the El Chichón eruption. Thus deposition of the $\mathrm{Na}_{2} \mathrm{SO}_{4}$ and $\mathrm{HCl}$ species recorded in the 90-1 pit could be a result of adsorption onto the tephra grains we located. Rose [1977] also observed the scavenging of $\mathrm{HCl}$ by tephra grains following the 1974 Fuego eruption, although his samples were close to the vent. Moreover, he estimated that only $17 \%$ of the $\mathrm{Cl}^{-}$emitted during the eruption was adsorbed onto tephra grains and thus quickly scavenged from the volcanic plume. Regardless of the actual process, it is apparent that there is a well-preserved $\mathrm{Cl}^{-}$signal in this particular pit from the El Chichón eruption.

\subsection{Other Snow Pits in the Summit Region}

Six pits dug during summer 1987 have records that extend at least back to summer or early spring 1982 . The record for pits 87-2, 87-4, and 87-5 (southern Summit region, Figure 1) end in early 1982 , while the record for pit 87-1 extends back to summer 1977, and the records for pits 87-6 and 87-7 (northern Summit region, Figure 1) extend back to summer 1979 (Figure 5). The two pits in the northern Summit region dug in 1990 (90-2 and 90-3; see Figure 1) have records that extend back to summer 1982 and to early 1983 , respectively (Figure 5).

There is evidence of the deposition of both $\mathrm{SO}_{4}^{2-}$ and $\mathrm{Cl}^{-}$aerosols from El Chichón in the many pits exca- vated in the Summit region, although the characteristics of these signals are not identical. This variability ranges from a lack of an anomalous signal, to more of a broad signal, as in pit 90-1, to a distinct spike above that of the seasonal peaks between late 1982 and early to late 1984 (Figure 5). A 2-year lag in deposition of aerosols in Greenland from an equatorial eruption is not unrealistic [Zielinski, 1995], especially considering that stratospheric $\mathrm{SO}_{4}^{2-}$ levels over the western United States were still 5 times background levels in January 1984 [Snetsinger et al., 1987]. Consequently, we infer that any peaks found in snow deposited in 1984 are primarily from the El Chichón eruption. The fact that some pits may have a signal in 1984, whereas others do not, may be a function of the heterogeneity of the volcanic plume over Greenland during the 2 years it was over the region. In addition, there is evidence of volcanic aerosol deposition from the abundant northern hemisphere eruptions beginning in 1979 and lasting to spring 1981 (Table 2). Several key aspects of our data set, as shown in Figure 5, are now briefly presented.

Evidence of the deposition of El Chichón $\mathrm{SO}_{4}^{2-}$ aerosols in the form of distinct peaks is found in four of the eight pits from the Summit region, with the possibility of a signal in two of the other pits. Peaks in $\mathrm{SO}_{4}^{2-}$ that probably are representative of El Chichón aerosols are found in pit 87-2 (fall 1984, winter 1983/spring 1984), in pit 87-4 (summer/fall 1984), in pit 87-5 (fall 1982), and in pit 90-3 (winter to spring 1984) (Figure 5). Slight enhancements in the $\mathrm{SO}_{4}^{2-}$ spring peak of 1984 in pits 87-1 and 87-6 may be from El Chichón aerosols, but the magnitude of the enhancement is small and not very convincing of a volcanic input. There is no clear volcanic signal in pit 87-7 related to El Chichón, but the elevated $\mathrm{SO}_{4}^{2-}$ baseline may be from a lengthy period of aerosol deposition as opposed to rapid deposition from perhaps a single snowfall. It is possible that postdepositional reworking of the snow by wind may have spread out the original signal, but we are not aware of any studies that would verify such a scenario. This may be the same situation that we see in the record from pit 90-1. Similarly, there is not a distinct peak in pit 90-2 within the likely time period for deposition of $\mathrm{El}$ Chichón debris.

Evidence for the deposition of the $\mathrm{Cl}^{-}$component of El Chichón is not found in as many pits as is that for the $\mathrm{SO}_{4}^{2-}$ component, but the signal is much more distinct where it is found. Very distinct $\mathrm{Cl}^{-}$spikes or at least enhanced seasonal spikes are observed in pit $87-1$ during the winter 1982 /spring 1983 snow and in pits 87-4 and 87-6 during the winter 1983/spring 1984 snow (Figure 5). Less preservation of the $\mathrm{Cl}^{-}$signal than of the $\mathrm{SO}_{4}^{2-}$ signal is not unexpected, because the greater solubility of the $\mathrm{Cl}^{-}$species in volcanic plumes results in quicker condensation and scavenging of the $\mathrm{Cl}^{-}$aerosols by supercooled water in relation to that for sulfur-bearing aerosols [e.g., Tabazadeh and Turco, 1993]. 

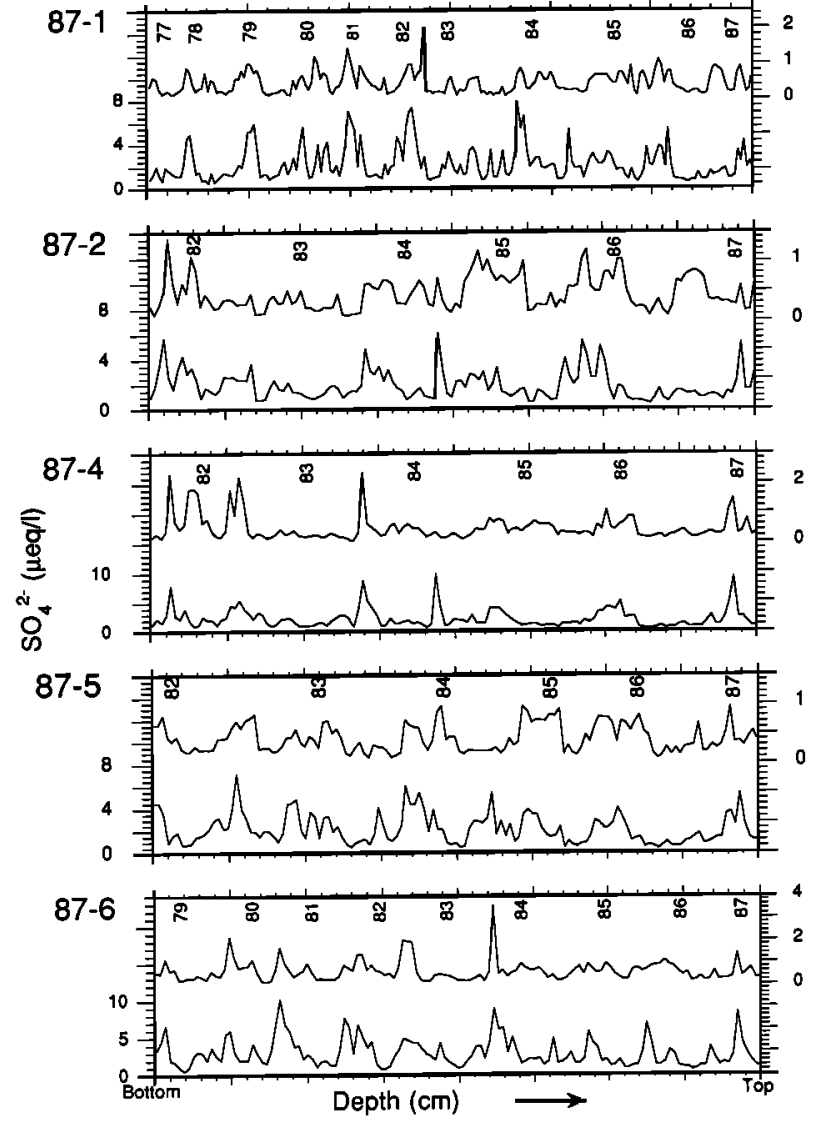
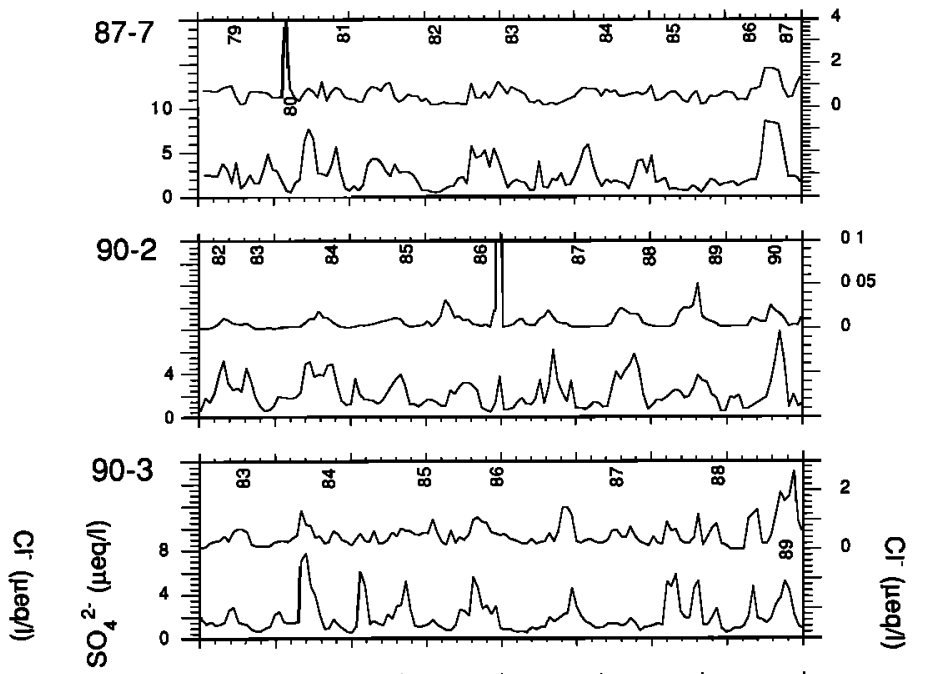

88-1

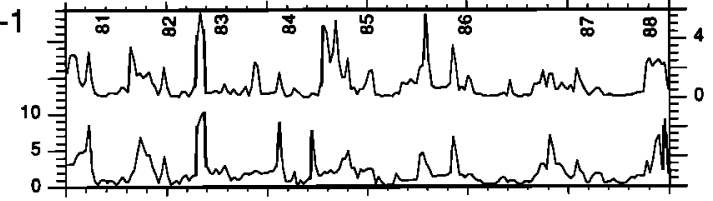

88-6

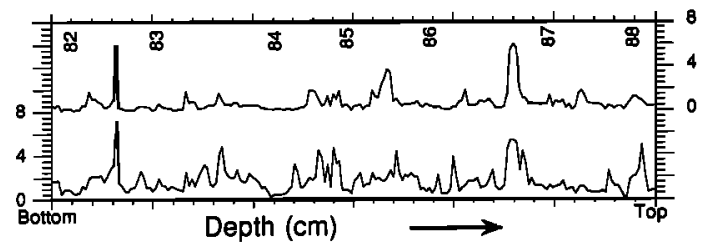

Figure 5. $\mathrm{SO}_{4}^{2-}$ and $\mathrm{Cl}^{-}$time series for 10 of the snow pits analyzed in this study. Year designation indicates the relative position of midsummer snow for that particular year. Pits 87-1, $88-1$, and 88-6 are $6 \mathrm{~m}$ deep (each major tick equals $1 \mathrm{~m}$ ). All remaining pits are $4 \mathrm{~m}$ deep (each major tick equals $50 \mathrm{~cm}$ ).

Deposition of volcanic aerosols from other eruptions during the 1980 s is observed through the presence of several spikes in either $\mathrm{SO}_{4}^{2-}$ or $\mathrm{Cl}^{-}$. There are spikes in both $\mathrm{SO}_{4}^{2-}$ and $\mathrm{Cl}^{-}$in pits 87-2 and 87-4 within winter 1981 /spring 1982 snow as well as a very broad spring peak in each species. These signals could be a result of the 1981 spring eruptions in the northern Pacific region (i.e., Alaid and Okmok; see Table 1). A large spike in $\mathrm{Cl}^{-}$in pit 87-7 within summer 1980 snow and a very broad $\mathrm{SO}_{4}^{2-}$ peak within fall 1980 snow may be a result of deposition from both tropospherically and stratospherically transported material from the 1980 Mount St. Helens eruption [e.g., Sedlacek et al., 1983; Kent and McCormick, 1984]. High concentrations during late 1986 and early 1987 in either $\mathrm{Cl}^{-}$(pit 90-2) or $\mathrm{SO}_{4}^{2-}$ (pit 87-7) could be a result of the St. Augustine and Chikurachki eruptions from the northern Pacific (Table 1).

\subsection{Northern and Southern Greenland}

There is a discernible $\mathrm{SO}_{4}^{2-}$ signal from El Chichón in both the northern Greenland pit 88-1 and the southern Greenland pit 88-6 (Figure 5). Both of these signals occur in the winter 1982/spring 1983 seasons, and they are the two largest spikes observed in each pit. In addition, there is a coincident $\mathrm{Cl}^{-}$spike in each pit, although the $\mathrm{Cl}^{-}$signal in pit 88-6 is more obvious in comparison with the $\mathrm{Cl}^{-}$time series for the rest of the pit than is the same signal in pit 88-1. Pit 88-6 also has broad $\mathrm{SO}_{4}^{2-}$ and $\mathrm{Cl}^{-}$spikes within late winter/spring 1987 snow. Again, the St. Augustine and Chikurachki eruptions would be the most likely candidates for those more recent signals. A broad but low peak at the bottom of pit 88-1 coincides with spring 1981 snow and thus could reflect deposition from the northern Pacific eruptions of 1981 (Table 1).

In addition to Pit 88-6 in southern Greenland, a shallower pit was dug near the 20D ice coring site [e.g., Lyons et al., 1990]. This second pit (20D) [Mayewski et al., 1987] only spans the 2-year period from summer 1984 to summer 1982 (Figure 6). The $\mathrm{SO}_{4}^{2-}$ record for spring 1983 is characterized by a very broad, enhanced baseline that may be a result of El Chichón aerosol deposition prior to deposition of the spring peak. The spring peak of 1984 also appears to be very broad with an initial smaller peak. The $\mathrm{Cl}^{-}$record displays several spikes during winter $1982 / 1983$. We cannot rule out that this increase in $\mathrm{Cl}^{-}$is from El Chichón, considering the timing of the northern hemisphere dispersion of 


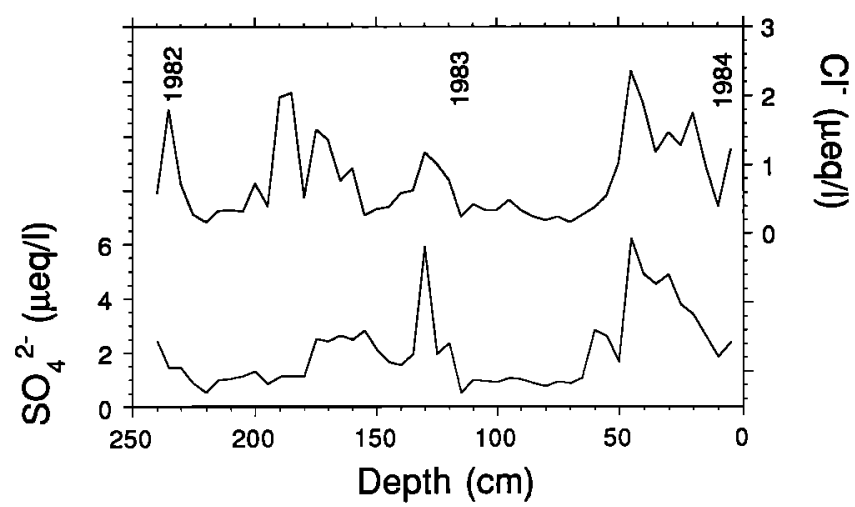

Figure 6. $\mathrm{SO}_{4}^{2-}$ and $\mathrm{Cl}^{-}$time series for pit 20D. Year designation indicates depth of midsummer snow for that particular year.

the stratospheric cloud. However, the shortness of the record from this pit makes it difficult to place the $\mathrm{SO}_{4}^{2-}$ and $\mathrm{Cl}^{-}$records in perspective in comparison with the rest of the 1980s. Nevertheless, Mayewski et al. [1987] postulated that the high amount of $\mathrm{SO}_{4}^{2-}$ and $\mathrm{Cl}^{-}$found in this pit compared with mean values in the $20 \mathrm{D}$ ice core was from deposition of El Chichón aerosols. They also used the data from this pit and the technique of Hammer et al. [1980] to suggest a stratospheric loading of $14 \mathrm{Mt} \mathrm{H}_{2} \mathrm{SO}_{4}$. We will expand on this estimate in a later section by using all the pits sampled in this study.

\subsection{Annual Flux}

To further evaluate the El Chichón signal, we calculated the annual flux of $\mathrm{SO}_{4}^{2-}$, thereby smoothing the original data sets. This method eliminates any potential dependency of the $\mathrm{SO}_{4}^{2-}$ record on accumulation, although Yang et al. [1996] showed that accumulation does not have an impact on $\mathrm{SO}_{4}^{2-}$ concentrations. More important, flux values are necessary to estimate the amount of stratospheric loading and climate-forcing potential of a volcanic eruption from the snow and ice record [e.g., Zielinski, 1995]. We only evaluated the $\mathrm{SO}_{4}^{2-}$ flux record because of the greater inconsistency in the $\mathrm{Cl}^{-}$signal. The annual flux of $\mathrm{SO}_{4}^{2-}$ for each snow pit is shown in Figure 7.

The most prominent characteristic of the flux data set is that maximum flux years are frequently found between 1982 and 1985, the years most likely to be influenced by the deposition of El Chichón aerosols (noting that our year is from summer to summer, and thus 1985 includes summer/fall 1984). In fact, one of these 3 years contains the highest annual flux in 9 of the 12 pits (i.e., 1982-1983, 3 pits; 1983-1984, 5 pits; and 1984-1985, 1 pit) or $75 \%$ of the pits. In almost every pit the year with the highest flux value had a high $\mathrm{SO}_{4}^{2-}$ concentration peak or contained an elevated $\mathrm{SO}_{4}^{2-}$ baseline (as represented by the presence of broad, subdued peaks) in that same year. Aerosols from the May 1982 Galunggung eruption may contribute to the high flux 1982-1985 but would probably be very minor in comparison with the
El Chichón component. Reported maximum height of the Galunggung cloud was only $16 \mathrm{~km}$, and most of the cloud appeared to move into the southern hemisphere [McClelland et al., 1989]. Maximum flux values also are found in 1981-1982 (two pits) and 1980-1981 (one pit). Maxima in these years probably reflect enhanced deposition of volcanic aerosols from the volcanic activity along the Northern Pacific Rim in 1979-1981 (Table 2). However, we must be cautious in using these results, as seven of the pits sampled failed to extend back to summer 1981, thus preventing a complete evaluation of the 1980s in all pits, and despite the prevalence of maximum values during 1982-1985, the magnitude of the flux in years with the greatest $\mathrm{SO}_{4}^{2-}$ flux commonly is not much higher than that for other years (e.g., pit 88-1; see Figure 7).

Spatial variability in the magnitude of the annual flux signals does not have a consistent trend. Highest peak flux values are found in the southern Summit region (pits 87-5 and 90-1; see Figure 7), but on the other hand, the lowest flux values are found in the southern Summit region as well (pits 87-1 and 87-2). There is not a large difference in the flux values among the one pit in northern Greenland (88-1, Figure 7) and the two pits from southern Greenland (88-6 and 20D, Figure 7). Furthermore, there is no consistent east-west trend in flux values across the divide, as maximum flux values in pits 87-7 and 90-2 (east of the divide) are intermediate in comparison with other pits, whereas flux values in pit 87-5 (east of the divide) are generally among the highest. Perhaps the only consistent spatial pattern that can be identified is that maximum flux values in pits from the southern Summit region and southern Greenland occur in 1982-1983 or 1983-1984, whereas those from the northern Summit region and northern Greenland occur anywhere between 1980-1981 and 1984-1985. However, we again caution that the record in only two of the pits from the southern Summit region and southern Greenland extend back beyond summer 1982. As a result there does not appear to be a preferred site in Greenland that would be more likely to preserve a northern equatorial eruption relative to another site.

\subsection{Composite Records}

As a final evaluation of the El Chichón signal we combined the annual concentration and flux records for each pit for each year to develop a composite record of $\mathrm{SO}_{4}^{2-}$ deposition for the period 1979-1989 as presented in the box plots in Figure 8. Pit 20D is not included in this analysis. Annual concentrations for this time period clearly show the influence of the abundant volcanism in the early 1980s. Median values for 1979-1980 to 19841985 are the highest of the period, with 1980-1981 being the highest (Figure 8a). The 1982-1983 median values are the second highest, but 11 pits are incorporated into that analysis, as compared with just four pits for 19801981. Composite $\mathrm{SO}_{4}^{2-}$ flux values further show the influence of volcanism in the early 1980 s, with median 

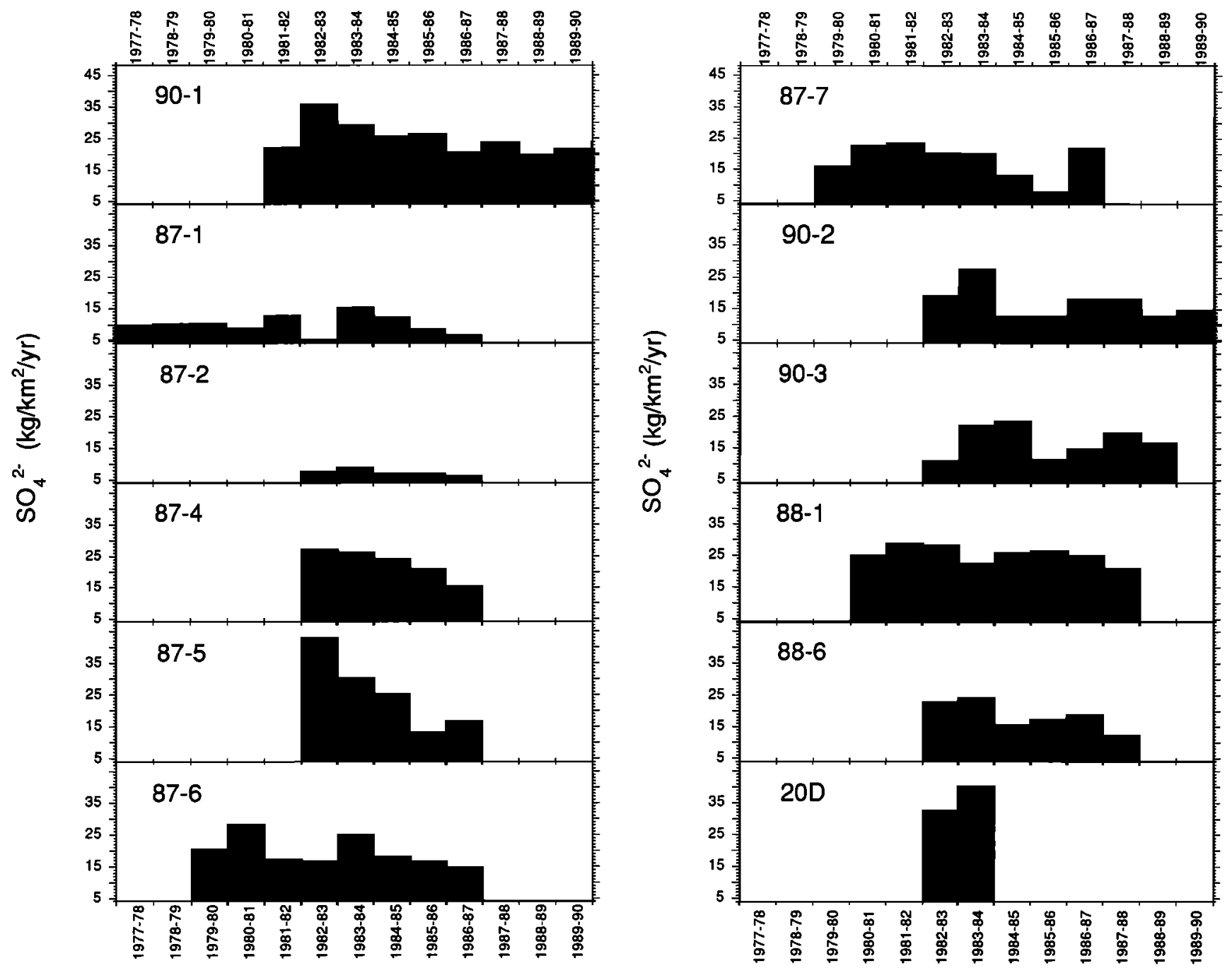

Figure 7. Annual $\mathrm{SO}_{4}^{2-}$ flux for all snow pits analyzed in this study. Yearly flux goes from midsummer of the earliest year shown to midsummer of the next year.

values for the periods $1980-1981$ to $1983-1984$ being the highest. Accounting for any influence from accumulation, flux for 1982-1983 is almost the same as that for 1980-1981. A second peak in $\mathrm{SO}_{4}^{2-}$ flux in 1986-1987 probably reflects the volcanic input of the Northern $\mathrm{Pa}$ cific eruptions during spring and fall 1986 (Table 2).

Of critical importance to the interpretation of the El Chichón signal is the magnitude of the $\mathrm{SO}_{4}^{2-}$ flux values during the 1980 s, values that include the volcanic component, the biogenic component, and especially the anthropogenic component. Median flux values range from $12 \mathrm{~kg} / \mathrm{km}^{2} / \mathrm{yr}$ for $1988-1989$ to a high of $29 \mathrm{~kg} / \mathrm{km}^{2} / \mathrm{yr}$ for $1980-1981$, with most median values in the $22-25 \mathrm{~kg} / \mathrm{km}^{2} / \mathrm{yr}$ range (Figure $8 \mathrm{~b}$ ). These values are a continuation of the recent increase in $\mathrm{SO}_{4}^{2-}$ deposition in the Summit region from anthropogenic sources [Mayewski et al., 1986, 1990]. $\mathrm{SO}_{4}^{2-}$ deposition is now up to twice the background levels of several centuries ago and up to $25 \%$ greater than background $\mathrm{SO}_{4}^{2-}$ levels at the turn of the century [Mayewski et al.,
1986,1990 ]. If we assume that the years $1987-1990$ are relatively free of volcanic input, then it appears that background $\mathrm{SO}_{4}^{2-}$ deposition is of the order of $18-20$ $\mathrm{kg} / \mathrm{km}^{2} / \mathrm{yr}$ for the 1980s (given that 1988-1989 appears to be anomalously low). This result would mean that volcanic $\mathrm{SO}_{4}^{2-}$ flux from El Chichón may be estimated by subtracting these background levels from the total of $26-28 \mathrm{~kg} / \mathrm{km}^{2} / \mathrm{yr}$ in the years $1982-1983$ and $1983-$ 1984 (Figure 8b). This calculation yields a volcanic $\mathrm{SO}_{4}^{2-}$ flux of about $6-8 \mathrm{~kg} / \mathrm{km}^{2} / \mathrm{yr}$ or a total volcanic flux from El Chichón of about $12-16 \mathrm{~kg} / \mathrm{km}^{2}$ for these 2 years.

If these assumptions are correct, then a total volcanic $\mathrm{SO}_{4}^{2-}$ flux from El Chichón of $12-16 \mathrm{~kg} / \mathrm{km}^{2}$ over a $2-$ year period is almost identical to that estimated in the biyearly sampling of the GISP2 core for the three eruptions of 1902, of which Santa Maria was the largest (i.e., a volcanic $\mathrm{SO}_{4}^{2-}$ flux of $14 \mathrm{~kg} / \mathrm{km}^{2}$ over a 2-year period [Zielinski, 1995]). Zielinski's [1995] maximum estimate of the stratospheric loading of the 1902 eruptions was 41 

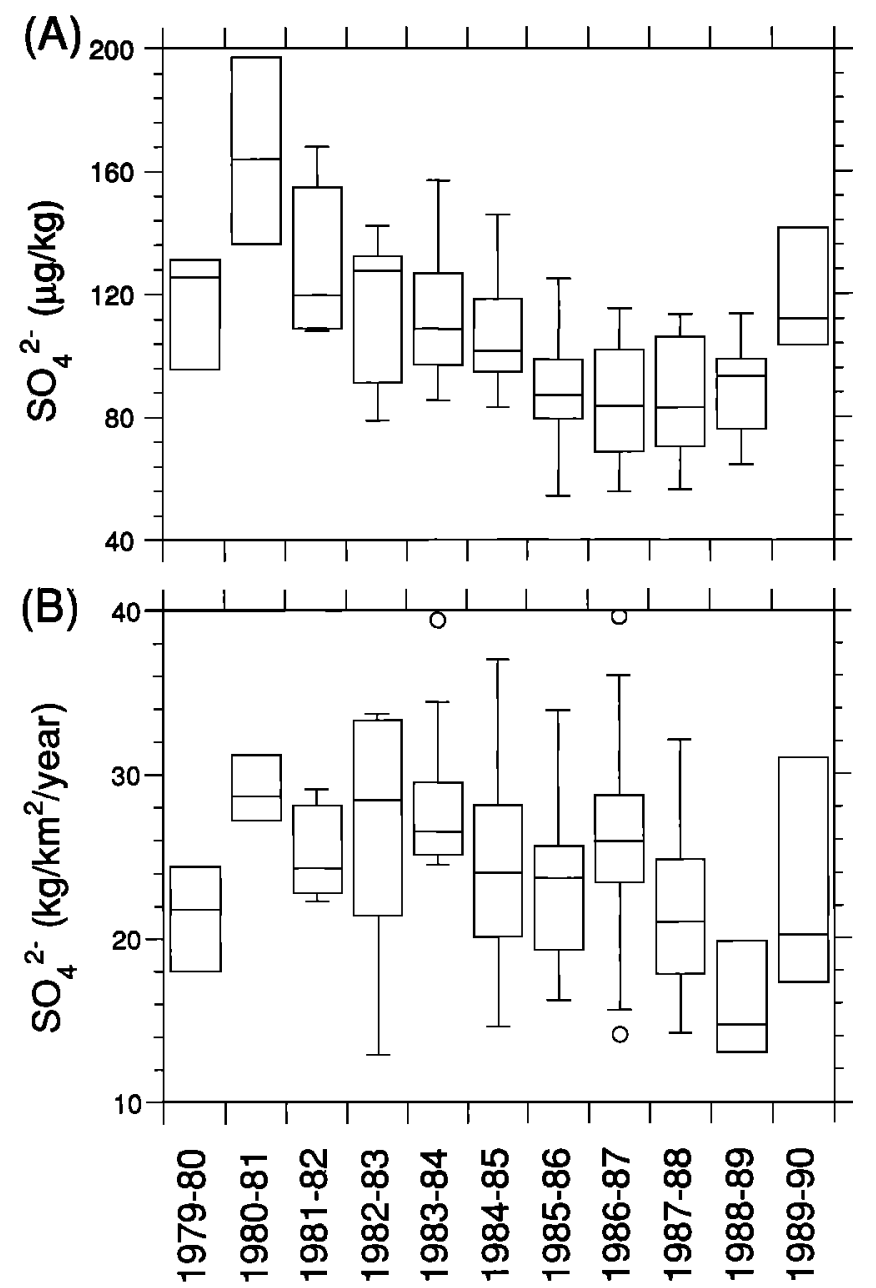

Figure 8. Box plots of composite (a) $\mathrm{SO}_{4}^{2-}$ concentrations and (b) annual $\mathrm{SO}_{4}^{2-}$ flux for all snow pits analyzed in this study. Years go from midsummer of the earliest year shown to midsummer of the later year. Solid line in each box represents the median value. Limits of the box include $50 \%$ of the data. Only some outliers (circles) shown.

$\mathrm{Mt}_{2} \mathrm{SO}_{4}$ aerosols, based on the hemispheric distribution of bomb fallout [Clausen and Hammer, 1988], resulting in a maximum optical depth $(\tau)$ of about 0.28 by using the relationship between stratospheric mass and optical depth of Stothers [1984]. Calibration of the estimated stratospheric loading of volcanic eruptions in the GISP2 core with the estimated optical depths from Sato et al. [1993] suggested that the ice core record may overestimate the stratospheric loading for some eruptions [Zielinski, 1995]. Thus the use of a correction factor resulted in intermediate and minimum optical depths of 0.13 and 0.06 , respectively, for the 1902 eruptions. If we use these same values for the El Chichón eruption, we obtain an estimated maximum $\tau$ of 0.28 for El Chichón, a value that agrees well with the 0.3 optical depth estimate presented by Hofmann [1987]. Our intermediate $\tau$ estimate of 0.13 (i.e., $20 \mathrm{Mt}$ ) agrees better with other estimations of $\tau$, such as the 0.15 value $(\sim 20$
Mt) given by Rampino and Self [1984] and Rampino et al. [1988], and with other $\mathrm{H}_{2} \mathrm{SO}_{4}$ loading estimates (i.e., $\sim 16 \mathrm{Mt}$, once $\mathrm{SO}_{2}$ is converted to $\mathrm{H}_{2} \mathrm{SO}_{4}$ [Bluth et al., 1993] and 12 Mt [McCormick et al., 1995]). Similarly, our $\tau$ estimate of 0.13 is appropriate, given the maximum range of optical depths found at $>60^{\circ} \mathrm{N}$ in late $1982(0.15-0.20)$ and in early $1983(0.10-0.15)$ [Sato et al., 1993]. Our minimum $\tau$ estimate of 0.06 matches the global mean $\tau$ of $\sim 0.06$ given by Sato et al. [1993].

\section{Discussion}

Our findings provide valuable information that addresses the questions we presented on (1) the variability of the El Chichón signal, (2) the signal:noise ratio as a function of sampling resolution, and (3) the possible influence that high levels of anthropogenic $\mathrm{SO}_{4}^{2-}$ may have on hindering the detection of an El Chichón signal and quantification of that signal. However, we initially point out that identifying volcanic glass from the El Chichón eruption in pit 90-1 verifies the deposition of material from the eruption in the Summit region of Greenland. Tephra was previously found around the Dye 3 drilling site in southern Greenland; thus debris from the eruption is now definitely known to have been deposited on at least central and southern Greenland. In the case of the record in pit 90-1 the tephra is found in the same layer of snow that contains a $\mathrm{Na}: \mathrm{Cl}$ ratio, in microequivalents of $1: 1$, unlike that for sea salt. This signal probably reflects deposition of the reactive components of halite with $\mathrm{H}_{2} \mathrm{SO}_{4}$ (i.e., $\mathrm{Na}_{2} \mathrm{SO}_{4}$ and $\mathrm{HCl}$ [Woods et al., 1995]), because halite was observed in the stratosphere following the eruption. Transport to and the eventual deposition on the ice sheet of the halite components may be via adsorption onto tephra grains. The appearance of $\mathrm{Cl}^{-}$in this snow pit as well as in several other pits indicates that $\mathrm{Cl}^{-}$aerosols are able to remain in the stratosphere for possibly up to one year after the eruption and are able to travel in the stratosphere well beyond the region immediately around the vent despite the fact that they are easily scavenged [e.g., Tabazadeh and Turco, 1993]. The appearance of distinct $\mathrm{Cl}^{-}$spikes in another ice core from Greenland that can be easily matched to known volcanic eruptions |Lyons et al., 1990] further supports this idea. Whether the magnitude of the stratospheric $\mathrm{Cl}^{-}$that reaches the polar region is sufficient to have a major impact on heterogenous chemical reactions (as in ozone depletion) in the upper atmosphere is another question. The small number of $\mathrm{Cl}^{-}$signals found in this study certainly does not support the notion of a large mass of El Chichónproduced $\mathrm{Cl}^{-}$aerosols remaining in the polar stratosphere 1 year after the eruption. These results provide information on the potential longevity of $\mathrm{Cl}^{-}$aerosols in the stratosphere and serve as additional evidence for the presence of El Chichón aerosols in Greenland snow.

We now focus our attention on the $\mathrm{SO}_{4}^{2-}$ record and the variability of the El Chichón signal. Peaks in $\mathrm{SO}_{4}^{2-}$ 
concentration that can be confidently linked to the $\mathrm{El}$ Chichón eruption are identified in only $50 \%$ of the pits sampled. Enhancements in the spring $\mathrm{SO}_{4}^{2-}$ signal in two other pits are not great enough to confidently link them to a volcanic input. These results could easily explain why there is not a distinct signal from El Chichón in the GISP2 core. However, there are several pits in which $\mathrm{SO}_{4}^{2-}$ concentrations within snow deposited between 1982 and 1984 are noticeably higher than background levels. Concentrations in these sections of the pits are equivalent to spring peaks in $\mathrm{SO}_{4}^{2-}$ (e.g., pit 90-1), but they are found in sections of the pit that do not correspond to spring snow. We believe that these sections with broad peaks in $\mathrm{SO}_{4}^{2-}$ are the result of a lengthy period of El Chichón aerosol deposition as opposed to deposition from a single snowfall event. This finding allows us to say that when evaluating a Greenland ice core at a subseasonal resolution, one can expect to find a signal from a northern equatorial eruption of a magnitude similar to that of El Chichón about two thirds of the time, at least under atmospheric conditions like the present. We will elaborate on this aspect of the record later.

The probable deposition of El Chichón aerosols over a period of months as opposed to scavenging by a single snowfall is evidenced further by our results from the annual $\mathrm{SO}_{4}^{2-}$ flux calculations. We found that by smoothing the snow pit record via the calculation of an annual flux we were able to increase the detectability of an El Chichón signal. Maximum annual flux during the years 1982-1983, 1983-1984, and 1984-1985 occur in 9 of the 12 pits sampled, suggesting that one has a $75 \%$ chance of observing a peak in annual $\mathrm{SO}_{4}^{2-}$ flux in a single ice core from Greenland, given a northern equatorial eruption of the magnitude of El Chichón. However, we use caution in putting forth this statement, as not all the pits sampled (Figure 7) extended back to the early 1980s and flux values in the years 1980-1982 were also quite high. In fact, volcanic activity during the 5-year period from 1980 to 1985 is abundant, especially in comparison with the later part of the 1980s. The high number of middle to high northern hemisphere eruptions in the early 1980s has increased the concentration of $\mathrm{SO}_{4}^{2-}$ in Greenland snow, and thus higher levels of $\mathrm{SO}_{4}^{2-}$ flux (Figure 8) to the ice sheet in the early 1980 s compared to those in the late 1980 s makes isolation of the El Chichón signal much harder than it would be if those eruptions had not occurred. The combined stratospheric loading of all of these northern hemisphere eruptions in the early 1980s is only about $1 \mathrm{Mt}$ [Kent and McCormick, 1984; McCormick et al., 1993], but there is a high probability that some portion, if not most, of the $\mathrm{SO}_{4}^{2-}$ deposited from these eruptions reached Greenland via tropospheric transport. In fact, McCormick and Trepte [1987] showed that optical depths in the Arctic began to rise prior to the time that El Chichón aerosols reached the region, but they suggested that this rise may be from the northward trans- port of aerosols from the equatorial Nyamuragira eruption in late 1981 (Table 1). Sedlacek et al. [1983] also measured high amounts of stratospheric $\mathrm{SO}_{4}^{2-}$ in the high latitudes of the northern hemisphere from these Northern Pacific eruptions. Thus this 5-year period of high volcanic $\mathrm{SO}_{4}^{2-}$ deposition could be another reason that the biannual sampling of the single GISP2 core could not isolate an El Chichón signal.

We used the concentration and annual flux time series of $\mathrm{SO}_{4}^{2-}$ to suggest that there is a $66-75 \%$ chance of observing the volcanic signal from a northern equatorial eruption of a magnitude similar to that of El Chichón in a single Greenland ice core, depending on sampling resolution. However, these numbers are a function of modern-day atmospheric conditions, when background $\mathrm{SO}_{4}^{2-}$ levels are much higher than those prior to the past 2 centuries. We can now evaluate how much of an impact this has on deciphering the El Chichón signal by first determining what percentage of the total $\mathrm{SO}_{4}^{2-}$ flux in the composite record is from El Chichón. We can then compare that percentage to the percentage of the total $\mathrm{SO}_{4}^{2-}$ flux that comes from volcanic eruptions that occurred prior to the major increase in atmospheric $\mathrm{SO}_{4}^{2-}$ from the industrial revolution. Provided that our assumptions are correct, we estimated that volcanic $\mathrm{SO}_{4}^{2-}$ flux from El Chichón is $6-8 \mathrm{~kg} / \mathrm{km}^{2} / \mathrm{yr}$ over the 2-year period $1982-1984$. The $6-8 \mathrm{~kg} / \mathrm{km}^{2} / \mathrm{yr}$ is only about one third the total $\mathrm{SO}_{4}^{2-}$ deposition or about $40 \%$ of background levels. Most explosive eruptions analyzed in the GISP2 core over the last 2100 years have volcanic fluxes that are at least $50 \%$ of the total $\mathrm{SO}_{4}^{2-}$ flux recorded at the time of the individual event and often over $66 \%$ of background $\mathrm{SO}_{4}^{2-}$ flux levels. Because background $\mathrm{SO}_{4}^{2-}$ flux levels over the last 2100 years (and especially prior to the industrial period) are generally 6.5 $7.5 \mathrm{~kg} / \mathrm{km}^{2} / \mathrm{yr}$ from the continuous biyearly sampling in the GISP2 core, sulfur-producing eruptions smaller than El Chichón, like the 1730 Lanzaroate event (Canary Islands), may have deposited about $5 \mathrm{~kg} / \mathrm{km}^{2} / \mathrm{yr}$ of $\mathrm{SO}_{4}^{2-}$ on the Greenland Ice Sheet. This value is $75 \%$ of background levels at that time, resulting in a very clear peak in $\mathrm{SO}_{4}^{2-}$ concentrations even with the biyearly smoothing of the continuous analyses [Zielinski et al., 1994; Zielinski, 1995]. Similarly, the Coseguina (Nicaragua) eruption, an eruption that may have been poor in sulfur despite the large volume erupted [Self et al., 1989], also deposited about $5 \mathrm{~kg} / \mathrm{km}^{2} / \mathrm{yr}$ of $\mathrm{SO}_{4}^{2-}$ or about $60 \%$ of background levels in the mid-1800s. There is a distinct spike for the Coseguina eruption in the GISP2 $\mathrm{SO}_{4}^{2-}$ record. Large eruptions like Tambora and Kuwae (A.D. 1450s) may have volcanic $\mathrm{SO}_{4}^{2-}$ fluxes that are 2-3 times background levels for the time of those eruptions. If pre-A.D. 1900 background levels existed now, then the El Chichón signal would be about equal to background levels as opposed to being only about $40 \%$ of background levels. The most viable explanation for these numbers is not that the $\mathrm{El}$ Chichón eruption was that much smaller than many 
of the explosive eruptions over the last 2100 years, but that identifying (via a distinct spike in the $\mathrm{SO}_{4}^{2-}$ record) and quantifying the volcanic component of the signal in Greenland snow is complicated by the high amount of anthropogenic $\mathrm{SO}_{4}^{2-}$ that is now being deposited on the ice sheet. Mayewski et al. [1987] alluded to the possible mixing of anthropogenic and volcanic $\mathrm{SO}_{4}^{2-}$ in the $20 \mathrm{D}$ pit.

These findings may be part of the reason why a signal from the large 1991 Pinatubo eruption has not been detected in Greenland snow as of yet (at least to the best of our knowledge) despite greater sulfur output from Pinatubo ( $\sim 30 \mathrm{Mt} \mathrm{SO}$ for Pinatubo versus $\sim 12$ Mt $\mathrm{SO}_{2}$ for El Chichón [McCormick et al., 1995]). One could hypothesize that the more equal global distribution of the Pinatubo aerosol cloud [McCormick et al., 1995] in comparison with the greater northern hemisphere distribution of the El Chichón cloud resulted in similar aerosol loadings in the northern polar region that would be available for deposition on the ice sheet. If this situation was true, then the chance of preserving an identifiable Pinatubo signal would be very similar to that for El Chichón given present anthropogenic $\mathrm{SO}_{4}^{2-}$ levels. Thus it is possible that there is a Pinatubo signal in recent Greenland snow, but it may exist more as a period with higher $\mathrm{SO}_{4}^{2-}$ baseline levels as opposed to a distinct $\mathrm{SO}_{4}^{2-}$ peak.

Our suggestion that anthropogenic $\mathrm{SO}_{4}^{2-}$ can complicate the identification of a volcanic signal would imply that the $66-75 \%$ chance of observing a volcanic signal from a northern equatorial eruption in a single ice core from Greenland possibly is low. How much too low is uncertain, but given the noise that occurs in the record, as evidenced in the high-resolution sampling, the actual probability of recording such an eruption may still be around $75 \%$. However, this still should be considered excellent, as there is no other medium that would preserve the far-reaching impact of hemispheric to global volcanism at such a level. The fact that our estimates of the stratospheric loading and the resulting optical depths for the El Chichón eruption (i.e., our intermediate estimates of $\sim 20 \mathrm{Mt}, \tau=0.13$ ) are close to estimates put forth by others further exemplifies the reliability of snow and ice core records in paleoclimatic research. However, our findings also show that evaluation of the volcanic record at different sampling resolutions, whenever possible, provides the information needed to better acquire reliable results.

\section{Conclusions}

We used a series of snow pits across the Summit region of Greenland and several from northern and southern Greenland to evaluate the variability in the record of the 1982 El Chichón eruption. The identification of volcanic glass in snow from spring 1983 verifies the deposition of material from the eruption in the Summit region. Evidence of the presence of components derived from the dissociation of halite through reactions with $\mathrm{H}_{2} \mathrm{SO}_{4}$ [Woods et al., 1985] in the same layer as the volcanic glass indicates that the $\mathrm{Cl}^{-}$component of an equatorial volcanic eruption is able to reach the polar stratosphere, possibly adsorbed onto silicate grains. Distinct spikes in $\mathrm{SO}_{4}^{2-}$ that we feel are related to $\mathrm{El}$ Chichón aerosol deposition were observed in only half the pits sampled, although periods of enhanced $\mathrm{SO}_{4}^{2-}$ concentrations in the form of broad subdued peaks (i.e., elevated baselines) were found in other pits. These data suggest that a northern equatorial eruption of the magnitude of $\mathrm{El}$ Chichón could be recorded about two thirds of the time in a single ice core from Greenland if sampled continuously at a subseasonal resolution. Annual $\mathrm{SO}_{4}^{2-}$ flux calculations essentially smooth the record, thus reducing the noise and increasing the chance of observing an El Chichón signal to about $75 \%$ of the time. However, the increase in anthropogenic $\mathrm{SO}_{4}^{2-}$ complicates identification and quantification of the El Chichón signal, as does the abundant middle to high northern latitude volcanism of the early 1980 s.

This study provides information on the possible variability in detecting a volcanic signal from moderate northern equatorial eruptions in Greenland ice and snow. Although we estimate that such a signal would be recorded in a single ice core about $75 \%$ of the time, the use of polar snow and ice to develop the chronology of past climate-forcing volcanism and quantify the magnitude of the forcing remains the best method to undertake an evaluation of volcanism-climate linkages for time periods prior to recent technological advances (i.e., satellite coverage). The limitations presented in this study should be beneficial to paleoclimatologists and modelers who use ice core records of volcanism in the evaluation of past climate change.

Acknowledgments. We are grateful to the many people who were involved in the excavation of these snow pits and in the analysis of the samples. In particular, we thank M. Hussey, C. Kingma, S. Drummey, C. Wake, M. Pender, J. Fiacco, J. James, and J. Wood. The Polar Ice Coring Office provided logistical support. Two anonymous reviewers made beneficial comments. Funding for this work was provided by the National Science Foundation Office of Polar Programs.

\section{References}

Angell, J.K., Impact of El Niño on the delineation of tropospheric cooling due to volcanic eruptions, J. Geophys. Res., 93, 3697-3704, 1988.

Bluth, G.J.S., C.C. Schnetzler, D.A.J. Krueger, and L.S. Walter, The contribution of explosive volcanism to global sulfur dioxide concentrations, Natune, 366, 327-330, 1993.

Buck, C.F., P.A. Mayewski, M.J. Spencer, S. Whitlow, M.S. Twickler, and D. Barrett, Determination of major ions in snow and ice cores by ion chromatography, J. Chromatogr., 594, 225-228, 1992.

Clausen, H.B., and C.U. Hammer, The Laki and Tambora eruptions as revealed in Greenland ice cores from 11 locations, Ann. Glaciol., 10, 16-22, 1988. 
De Angelis, M., L. Fehrenbach, C. Jehanno, and M. Maurette, Micrometre-sized volcanic glasses in polar ices and snow, Nature, 317, 52-54, 1985.

Dibb, J.E., and S.I. Whitlow, Recent climate anomalies and their impact on snow chemistry at South Pole, 1987-1994, Geophys. Res. Lett., 23, 1115-1118, 1996.

Evans, W.F.J., and J.B. Kerr, Estimates of the amount of sulphur dioxide injected into the stratosphere by the explosive volcanic eruptions: El Chichón, Mystery Volcano, Mt. St. Helens, Geophys. Res. Lett., 10, 1049-1051, 1983.

Fiacco, R.J. Jr., J.M. Palais, M.S. Germani, G.A. Zielinski, and P.A. Mayewski, Characteristics and possible source of a 1479 A.D. volcanic ash layer in a Greenland ice core, Quat. Res., 39, 267-273, 1993.

Gooding, J.L., U.S. Clanton, E.M. Gabel, and J.L. Warren, El Chichón volcanic ash in the stratosphere: Particle abundances and size distribution after the 1982 eruption, Geophys. Res. Lett., 10, 1033-1036, 1983.

Hammer, C.U., H.B. Clausen, and W. Dansgaard, Greenland ice sheet evidence of post-glacial volcanism and its climatic impact, Nature, 288, 230-235, 1980.

Hofmann, D.J., Perturbations to the global atmosphere associated with the El Chichón volcanic eruption of 1982, Rev. Geophys., 25, 743-759, 1987.

Hofmann, D.J., and J.M. Rosen, Stratographic sulfuric acid fraction and mass estimate for the 1982 volcanic eruption of El Chichón, Geophys. Res. Lett., 10, 313-316, 1983.

Kent, G.S., and M.P. McCormick, SAGE and SAM II measurements of global stratospheric aerosol optical depth and mass loading, J. Geophys. Res., 89, 5303-5314, 1984.

Legrand, M., and R.J. Delmas, A 220-year continuous record of volcanic $\mathrm{H}_{2} \mathrm{SO}_{4}$ in the Antarctic Ice Sheet, Nature, 327, 671-676, 1987.

Luhr, J.F., I.S.E. Carmichael, and J.C. Varekamp, The 1982 eruptions of El Chichón Volcano, Chiapas, Mexico: Mineralogy and petrology of the anhydrite-bearing pumices, J. Volcanol. Geotherm. Res., 23, 69-108, 1984.

Lyons, W.B., P.A. Mayewski, M.J. Spencer, M.S. Twickler, and T.E. Graedel, A northern hemisphere volcanic chemistry (1869-1984) and climatic implications using a south Greenland ice core, Ann. Glaciol., 14, 176-182, 1990.

Mankin, W.G., and M.T. Coffey, Increased stratospheric hydrogen chloride in the El Chichón cloud, Science, 226, 170-172, 1984.

Mayewski, P.A., W.B. Lyons, M.J. Spencer, M. Twickler, W. Dansgaard, B. Koci, C.I. Davidson, and R.E. Honrath, Sulfate and nitrate concentrations from a south Greenland ice core, Science, 232, 975-977, 1986.

Mayewski, P.A., M.J. Spencer, W.B. Lyons, and M.S. Twickler, Seasonal and spatial trends in south Greenland snow chemistry, Atmos. Environ., 21, 863-869, 1987.

Mayewski, P.A., W.B. Lyons, M.J. Spencer, M.S. Twickler, C.F. Buck, and S. Whitlow, An ice core record of atmospheric response to anthropogenic sulphate and nitrate, Nature, 346, 554-556, 1990.

Mayewski, P.A., G. Holdsworth, M.J. Spencer, S. Whitlow, M. Twickler, M.C. Morrison, K.K. Ferland, and L.D. Meeker, Ice core sulfate from three Northern Hemisphere sites: Source and temperature forcing implications, Atmos. Environ., Part A, 27, 2915-2919, 1993.

McCormick, M.P., and C.R. Trepte, Polar stratospheric optical depth observed between 1978 and 1985, J. Geophys. Res., 92, 4297-4306, 1987.

McCormick, P.M., P.H. Wang, and L.R. Poole, Stratospheric aerosols and clouds, in Aerosol-Cloud-Climate Interactions, edited by P.V. Hobbs, Pp. 205-222, Academic, San Diego, Calif., 1993.
McCormick, M.P., L.W. Thomason, and C.R. Trepte, Atmospheric effects of the Mt. Pinatubo eruption, Nature, 373, 399-404, 1995.

McClelland, L., T. Simkin, M. Summers, E. Nielsen, and T.C. Stein, Global Volcanism 1975-1985, Prentice-Hall, Englewood Cliffs, N.J., 1989.

Palais, J.M., and H. Sigurdsson, Petrologic evidence of volatile emissions from major historic and pre-historic volcanic eruptions, in Understanding Climate Change, Geophys. Monogr. Ser., vol. 52, edited by A. Berger, R.E. Dickinson, and J.W. Kidson, pp. 31-53, AGU, Washington, D.C., 1989.

Rampino, M.R., and S. Self, Sulphur-rich volcanic eruptions and stratospheric aerosols, Nature, 310, 677-679, 1984.

Rampino, M.R., S. Self, and R.B. Stothers, Volcanic winters, Annu. Rev. Earth Planet. Sci., 16, 73-99, 1988.

Robock, A., and M.P. Free, Ice cores as an index of global volcanism from 1850 to the present, J. Geophys. Res., 100, 11,549-11,567, 1995.

Robock, A., and M. Matson, Circumglobal transport of the El Chichón volcanic dust cloud, Science, 221, 195-197, 1983.

Rose, W.I. Jr., Scavenging of volcanic aerosol by ash: Atmospheric and volcanologic implications, Geology, 5, 621$624,1977$.

Sato, M., J.E. Hansen, M.P. McCormick, and J.B. Pollack, Stratospheric aerosol optical depths, 1850-1990, J. Geophys. Res., 98, 22,987-22,994, 1993.

Sedlacek, W.A., E.J. Mroz, A.L. Lazrus, and B.W. Gandrud, A decade of stratospheric sulfate measurements compared with observations of volcanic eruptions, J. Geophys. Res., 88, 3741, 1983.

Self, S., M.R. Rampino, and M.J. Carr, A reappraisal of the 1835 eruption of Cosigüina and its atmospheric impact, Bull. Volcanol., 52, 57-65, 1989.

Shapiro, M.A., R.C. Schnell, F.P. Parungo, S.J. Oltmans, and B.A. Bodhaine, El Chichón volcanic debris in an Arctic tropopause fold, Geophys. Res. Lett., 11, 421-424, 1984.

Siebe, C., M. Abrams, J.L. Macias, and J. Obenholener, Repeated volcanic disasters in Prehispanic time at Popocatépal, Central Mexico: Past key to the future?, Geology, 24, 399-402, 1996.

Simkin, T., and L. Siebert, Volcanoes of the World, 2nd ed., 349 pp., Geoscience, Tucson, Ariz., 1994.

Snetsinger, G.V., G.V. Ferry, P.B. Russell, R.F. Pueschel, V.R. Oberbeck, D.M. Hayes, and W. Fong, Effects of El Chichón on stratospheric aerosols late 1982 to early 1984 , J. Geophys. Res., 92, 14,761-14,771, 1987.

Stothers, R.B., Mystery cloud of A.D. 536, Nature, 307, 344-345, 1984.

Tabazadeh, A., and R.P. Turco, Stratospheric chlorine injection by volcanic eruptions: $\mathrm{HCl}$ scavenging and implications for ozone, Science, 260, 1082-1086, 1993.

Varekamp, J.C., J.F. Luhr, and K.L. Prestegaard, The 1982 eruptions of El Chichón volcano (Chiapas, Mexico): Character of the eruptions, ash-fall deposits, and gas phase, $J$. Volcanol. Geotherm. Res., 23, 39-68, 1984.

Whitlow, S., P.A. Mayewski, and J.E. Dibb, A comparison of major chemical species seasonal concentration and accumulation at the South Pole and Summit, Greenland, Atmos. Environ., Part A, 26, 2045-2054, 1992.

Woods, D.C., R.L. Chuan, and W.I. Rose, Halite particles injected into the stratosphere by the 1982 El Chichón eruption, Science, 230, 170-172, 1985.

Yang, Q., P.A. Mayewski, E. Linder, S. Whitlow, and M. Twickler, Chemical species spatial distribution and re- 
lationship to elevation and snow accumulation rate over the Greenland Ice Sheet, J. Geophys. Res., 101, 18,629$18,637,1996$.

Zielinski, G.A., Stratospheric loading and optical depth estimates of explosive volcanism over the last 2100 years derived from the GISP2 Greenland ice core, J. Geophys. Res., 100, 20,937-20,955, 1995.

Zielinski, G.A., P.A. Mayewski, L.D. Meeker, S. Whitlow, M.S. Twickler, M. Morrison, D. Meese, R.B. Alley, and A.J. Gow, Record of volcanism since 7000 B.C. from the GISP2 Greenland ice core and implications for the volcano-climate system, Science, 264, 948-952, 1994.
J. E. Dibb, P. A. Mayewski, M. S. Twickler, S. Whitlow, Q. Yang, and G. A. Zielinski, Climate Change Research Center, Institute for the Study of Earth, Oceans, and Space, University of New Hampshire, Morse Hall, Durham, NH 03824. (email: jed@unh.edu; p_mayewski@unh.edu; mark.twickler@unh.edu; qinzhao.yang@unh.edu; Greg.Zielinski@unh.edu)

M. S. Germani, MVA, Inc., Burr Ridge, IL 60521. (e-mail: GermaniMS@aol.com)

(Received November 21, 1996; revised March 24, 1997; accepted May 24, 1997.) 